\title{
Implementing Social Media: Practical Reflections From County Governments During Hurricane Matthew
}

\author{
Wanzhu Shi, Texas A\&M International University, USA \\ Pamela Medina, California State University, San Bernardino, USA
}

\begin{abstract}
Social media is an important avenue for information dissemination and public communication in emergency management. Through social media content analysis and in-depth interviews, this study explores how county-level emergency management agencies use their Facebook pages to communicate with the public, using Hurricane Matthew as a case study. The findings reveal some areas of congruence between literature and practitioner experience. The results suggest that public agencies integrate flexible social media strategies, which emphasize one-way communication when the public expects larger volumes of information and directions, and two-way communication when the public might have individualized needs. Furthermore, the findings show that visual content (e.g., pictures) are more likely to garner higher levels of public engagement on Facebook. Last, the study provides several practical suggestions for content creation and interaction on social media for emergency purposes.
\end{abstract}

\section{KEYWORDS}

County Government, Emergency Communication, Emergency Management, Facebook, Hurricane Mathew, Public Engagement, Social Media, Social Media Strategies

\section{INTRODUCTION}

On October 10, 2016, Hurricane Matthew made landfall in Florida, as the first major hurricane to hit Florida in over a decade. This Category 5 storm was responsible for 12 deaths and over $\$ 2.5$ billion in damages within the state of Florida alone (National Centers for Environmental Information, 2017). Given the advances in communication technology adopted up to this time, Hurricane Matthew also represented the first time that social media would be used in the full life cycle of a major disaster in the state of Florida, including mitigation, preparedness, response, and recovery.

The American Red Cross reports that most Americans believe social media should be used for emergency communication with the public (Briones, 2011), and a growing body of evidence cites the contributions of social media in emergency communication (Hughes \& Palen, 2012; Kavanaugh et al., 2012; Latonero \& Schkovski, 2013; Luna \& Pennock, 2018; Neely \& Collins, 2018). These innovative tools are particularly useful in emergency situations because of their ability to provide real-time communication to broad audiences (Yates \& Paguette, 2011). With more than 2.23 billion monthly active users on Facebook alone (Facebook, 2018) social networking features can capitalize on audience participation, and permit two-way information sharing between residents and government, as well as residents and one another (Luna \& Pennock, 2018). Emerging research has also highlighted 
many challenges with social media use. Of these, studies indicate a need for better understanding the management of social media, including understanding the changing role of those who manage information, concerns about accuracy and utility of citizen content on social media, and management of updates and accounts during emergency scenarios (Reddick \& Norris, 2013; Wukich \& Mergel, 2016).

However, the collection and analysis of real-time data on social media remains a challenge (Yuan, Li, \& Liu, 2020). For instance, to date most studies use social media data collected from Twitter, often due to ease of accessibility in data collection resulting from permissions granted by the company (Hughes \& Palen, 2009; Latonero \& Shklovski, 2013; Martinez-Rojas et al., 2018). However, current data shows that there are more Facebook users than Twitter users worldwide (Statista, 2020). Additionally, although several studies attempt to use "big data" to analyze government use of social media during emergencies (Wang et al., 2016; Xu et al., 2016), these analyses are primarily quantitative, and may not capture nuanced detail or provide practical advice to public managers (Gelo et al., 2008; Toomela, 2008).

The present article contributes to the better understanding of a major social media platform in emergency management situations by analyzing the use of Facebook by county governments during Hurricane Matthew. The study considers two exploratory research questions, one of which is about contemporary use and the other about effectiveness of comparative practices:

Research Question \#1: How have county governments typically used and managed Facebook pages for emergency communication? This research question aims to explore the congruence between scholarly recommendations and practical implementation, capitalizing on qualitative inquiry.

Research Question \#2: What characteristics of social media content on Facebook are most successful in capturing the public's attention? This research question compares interaction data based on differences in content.

This study first reviews relevant literature on emergency communication and the role of social media within the emergency management context. Next, using a mixed-methods approach, the study examines county government Facebook posts before, during, and after Hurricane Matthew. We follow with in-depth interviews with public administrators sharing the primary responsibility of managing social media-based emergency communication before leading into findings and practical recommendations.

\section{LITERATURE REVIEW}

\section{The Nature of Emergency Communication}

Studies indicate that citizens turn to the government as their main source for emergency information (Kavanaugh et al., 2012). Accordingly, Federal Emergency Management Agency (FEMA) guidance for Public Information Officers (PIO)'s recommends that this information be gathered from multiple sources including the public, technical specialists, etc., be verified, produced after internal coordination to ensure consistency, and importantly, communicated via multiple channels, including news releases, e-mails, texts, reverse 911, etc. (FEMA, 2010, p. c-9).

While the primary method of information dissemination has generally been through traditional media, mostly in the form of televised news (Liu et al., 2012), the effectiveness of traditional media is varied. For instance, studies find that traditional media sources are more likely to disseminate inaccurate information, especially as it changes rather quickly (Garnett \& Kouzmin, 2007). Others note that the high volume of public demand for information also presents a challenge for use of slower traditional media outlets (Liu et al., 2012). As a result, social media have been used in a variety of emergency scenarios for various purposes, including disseminating information, promoting 
and receiving donations, providing information on assistance and recovery, memorializing victims, coordinating activities, and connecting members of the community (Luna \& Pennock, 2018).

\section{The Role of Social Media in Emergency Communication}

Social media are defined as "a group of Internet-based applications that build on the ideological and technological foundations of Web 2.0 and that allow the creation and exchange of user-generated content" (Kaplan \& Haenlein, 2010, p. 61). Social networking sites like Twitter and Facebook are most widely used (Kagarise and Zavattaro, 2017). Disasters are viewed as "inherently social" occurrences (Aldrich \& Meyer, 2015), and literature underlines the role of social capital and community resilience in managing emergencies. For instance, people directly impacted by events, and often on the front lines, turn to one another and can be leveraged to transmit information to public officials in the Whole Community approach to emergency management (FEMA, 2011). To do so, communicating agencies must cultivate strong relationships with stakeholders, understand the unique needs of different audiences, and manage expectations from organizations and citizens (Ulmer et al., 2017; Aldrich \& Meyer, 2015; Plotnick \& Hiltz, 2016). Social media's interactive features provide some capacity to address these concerns through the combined use of both push and pull strategies (Mergel, 2013; Houston et al., 2015; Wukich, 2020; Plotnick \& Hiltz, 2016; Chatfield \& Reddick, 2018).

In the push, or one-way strategy, social media are used primarily as an information dissemination tool. An effective 'push' approach is timely and accurate, provides customized or innovative forms of content (such as video streams, photos, etc.), and has a large population reach (Mergel, 2013; Graham et al., 2015; Chatfield \& Reddick, 2018; Gruzd et al., 2018; Meltzer et al., 2018; Neely \& Collins, 2018). Research also suggests that managing ambiguity is important, and communication should emphasize telling the public which aspects of the situation are uncertain, as well as who is affected, what the public should do, and who they can trust (Ulmer et al., 2017). Chatfield and Reddick highlight three major goals in improving emergency communication: increased communication speed, improved reach to get the message to the intended audience and ensuring that information is of high quality (2018). To that end, it is also sometimes recommended that to improve the quality and accuracy of public communication, these approaches should incorporate opportunities for public feedback (Liu et al., 2012).

In the push and pull approach, or two-way strategy, social media are used as an interactive tool, encouraging the public to communicate in two-way information sharing (Kaplan \& Haenlein, 2010; Briones et al., 2011; Mergel, 2013; Hiltz et al., 2014). Kavanaugh et al. (2012) note that the two-way approach can help governments deliver more accurate information on their social media, as well as foster a sense of responsiveness. The effectiveness of these strategies is contingent upon infrastructure, policy, and management of social media. Of course, in practice the quality of engagement is highly variable, highlighting the need for developing strategies that are appropriate and pragmatic for use in various contexts (Medina \& Bryer, 2019).

While the literature consistently highlights the importance of using both push and pull strategies, the practitioner experience implementing these recommendations is varied. For instance, in a 2016 study using interviews with county emergency managers, Plotnick and Hiltz find that many counties with smaller populations do not have the funds to invest in social media infrastructure at all, or the staff to manage it (2016). Indeed, as communication opportunities evolve, so too has the role of the Public Information Officer (PIO's) (Hughes \& Palen, 2012). Hughes and Palen (2012) find that PIO's now serve more as translators of information, rather than information gatekeepers. Rather than producing information and being responsible for who has access to it and how, PIO's must monitor and control messaging that the public can also directly contribute to.

Contemporary research further notes that "the distribution of social media tasks is relevant", and more research is needed to understand how content is designed, monitored, and how tasks are assigned, an area missing from the general research (Wukich, 2020, p. 24). Plotnick and Hiltz (2016) further emphasize this, also noting that there is insufficient guidance or policy on customizing content and 
using two-way strategies to pull information. This coincides with larger scale studies, one of which notes that approximately only $19 \%$ of city governments had adopted specific social media use policies by 2017, even though this is an academically recommended practice (Bennet \& Manoharan, 2017).

Indeed, there is a need for more research on exploring the practitioner's experience in managing social media-including understanding use, from development of effective content through task and role assignment. In the following sections, we use a convergent-parallel mixed methods approach combining content analysis and in-depth interviews (Creswell \& Clark, 2017) to address these questions.

\section{METHODOLOGY}

\section{Sample Selection}

The study sample was selected based on multiple factors. First, counties in Florida were selected because Florida was the first state to declare a state of emergency as a result of the impending storm (Reuters, 2016). Selecting counties from one state allows for more comparability across counties. Additionally, Florida statute mandates that all counties must have an emergency response plan, indicating that counties are an appropriate level of government for exploring emergency communication (Kapucu, 2008). Therefore, the study uses a purposive sample of twenty-four counties $(\mathrm{N} 1=24)$ within the direct trajectory of Hurricane Matthew as of October 2016 (see Figure 1). The study did not select non-directly impacted counties because most of them did not need to evacuate, rescue, or engage in recovery during this incident, indicating their lack of engagement in the full emergency management cycle. A list of socio-demographic information for these counties are provided in the appendix.

\section{Social Media Content Analysis}

Quantitative data for content analysis were acquired from each county's Facebook page, with each post serving as the unit of analysis. From this, data collection included post content type (text, photo, video, or a combination of each), as well as post engagement (likes, comments, and shares). Facebook was selected because existing research finds that Facebook is the primary communication tool among local governments during crises (Graham et al., 2015). Among the twenty-four counties included in the sample, only one did not have a dedicated Emergency Management department, with emergency management functions performed instead by the Sheriff's department. In this case, the Sheriff department's Facebook page was used as an alternative. All counties had established a dedicated profile on Facebook.

Posts were searched using the keywords "Hurricane Matthew" between September 28th (the first date a post about the hurricane was made) through October 30th, 2016. This timeline was selected following the sequence of before, during, and after Hurricane Matthew. In total, the content analysis included 955 total Facebook posts from the 24-county sample.

\section{Interviews}

An invitation was sent to all twenty-four selected county agencies for in-depth interviews. From this, eleven counties $(\mathrm{N} 2=11)$ with thirteen staff, including Emergency Management Directors, Public Relations Officers, Public Information Officers, and Social Media Specialists agreed to participate leading to a response rate of approximately $46 \%$ (denoted in dark gray, in figure 1). According to work by Glaser and Strauss (1967), 75\% of codes required for data saturation occur by six interviews with data saturation occurring by interview twelve, indicating that the sample size of eleven was appropriate for the nature of this exploratory study. The sample includes a mix of large and small counties, representative of the demographics of the counties within the direct trajectory of the storm. County population and economic data, along with organizational missions as reported on each agencies' Facebook page, are provided in the appendix. 


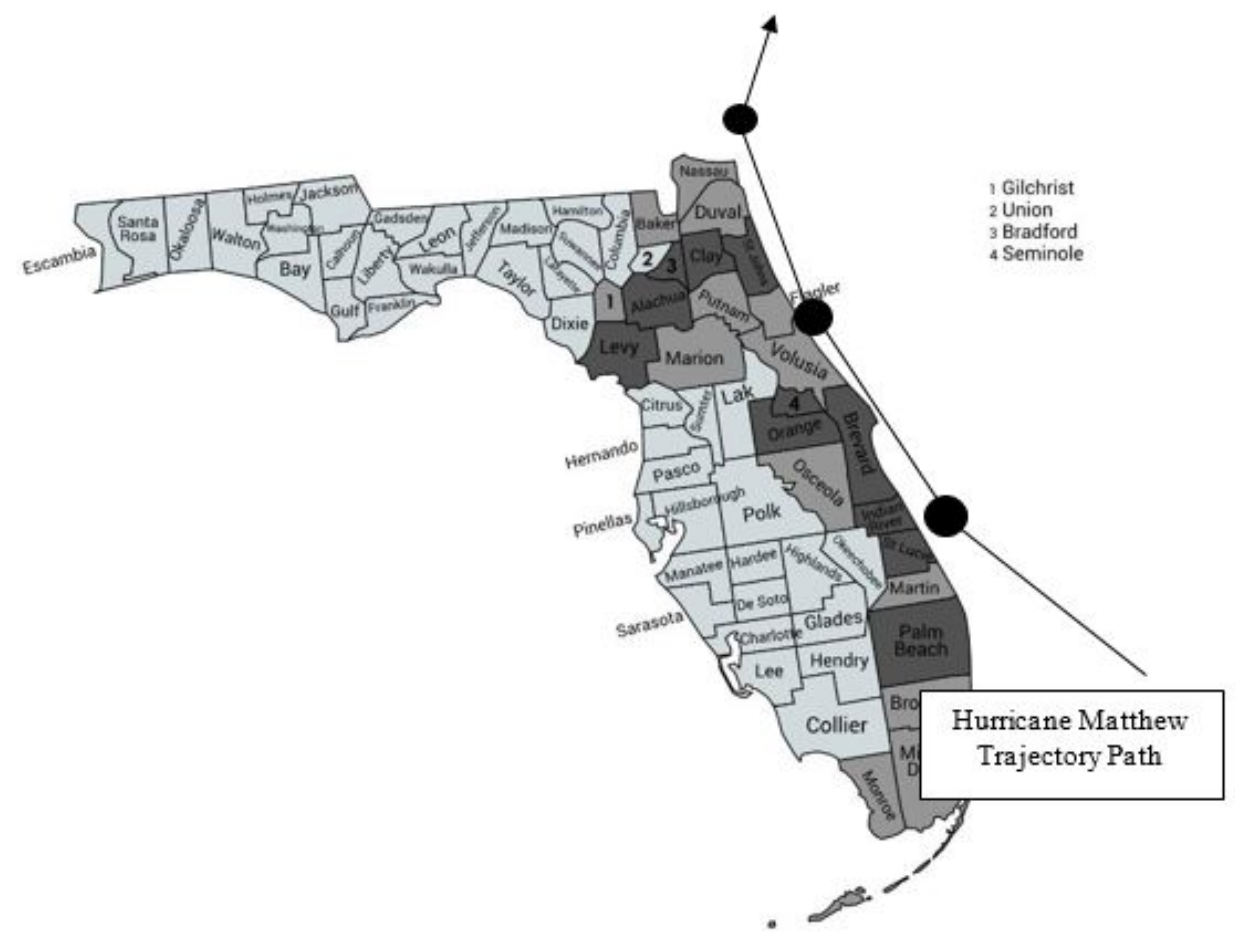

* Both $\square$ and $\square$ areas represent the counties we selected in our sample

* Areas represent the counties, which participated in our in-depth interviews

Interviews were conducted by phone from July to September 2018. Two researchers were trained with the interview protocol first, and then conducted the phone interviews separately. The interview questionnaire covered nine themes with twenty-one questions. Major themes included the general use of social media, strategic priorities, personnel management, social media content management, management across phases of the emergency management cycle, challenges, successes, perceptions of public values, and use of resources. The interviews were transcribed, and both interviewers engaged in a pilot coding process of two interviews in order to ensure inter-rater reliability. Reliability in coding was achieved at a rate above $90 \%$. Coding was conducted using an inductive "lean coding" approach (Creswell \& Clark, 2017).

The following section presents the results of the mixed-method study, using a convergent parallel design by interpreting results of the qualitative and quantitative components simultaneously (Creswell \& Clark, 2017). The study first provides a general picture of how county-level emergency management agencies used social media to communicate with citizens during Hurricane Matthew. This includes a discussion of post activity and content, as well as management goals, objectives, and strategies based on interview data. Next, we examine how variations in content type relate to differences in public engagement. 


\section{FINDINGS AND DISCUSSION}

\section{County-Level Social Media Activity During Hurricane Matthew}

To understand how county governments used social media, we began with a simple analysis of variations in post frequency, before, during, and after hurricane landfall. Considering the scale of the emergency, posts between October 10th through October 17th, 2016 were considered to occur "during the event". Table 1 shows that among all the collected posts, counties posted 605 (63.4\%) posts before the hurricane, $142(14.8 \%)$ posts during the hurricane, $178(18.6 \%)$ posts after the hurricane. The range of posts was between a low of 2 and a high of 157, with an average of 40 total posts and a standard deviation of 42 , indicating a high level of variation in post frequency across agencies.

Table 1. Frequency Distribution of County Governments' Facebook Usage

\begin{tabular}{|l|l|l|l|}
\hline $\begin{array}{l}\text { Phases in Emergency } \\
\text { Management }\end{array}$ & $\begin{array}{l}\text { Ave. posts /per agency / } \\
\text { per day }\end{array}$ & Number of posts & Percentage \\
\hline Preparedness & 2.04 & 635 & $66.5 \%$ \\
\hline Response & 0.85 & 142 & $14.9 \%$ \\
\hline Recovery & 0.04 & 178 & $18.6 \%$ \\
\hline Total & 1.17 & 955 & $100 \%$ \\
\hline
\end{tabular}

Figure 2 illustrates the post volume among the county agencies during Hurricane Matthew, which is a good indicator of the timeline in agencies' emergency management operations. The peak moment of Facebook volume was achieved three days (72 hours) before the hurricane's landfall, which coincides with FEMA's suggestion for local governments to activate the hurricane emergency operation plan 5 days to 72 hours prior to an expected landfall (FEMA, 2010). The volume of posts

Figure 2. Hurricane Matthew Timeline and the County Governments' Social Media Volume in the Emergency Management Cycle

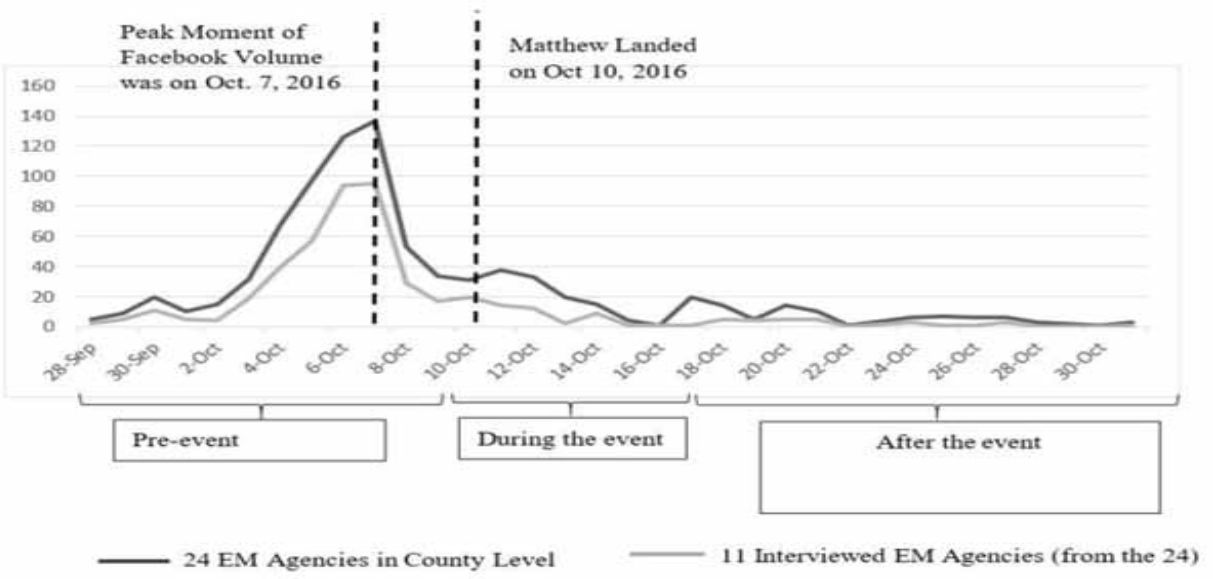


dropped dramatically the day before and during the hurricane. An interviewee highlighted some potential reasons for these variations, noting:

We were typically very active 3 or 4 days before landfall for preparation. During the event though, we don't use [social media] that much. We post some necessary updates and try to let our citizens stay calm. After the hurricane happens, our citizens expect to see us in the field, not just on social media.

\section{Social Media Management}

Summarized in Table 2, thematic analysis indicated that most organizations listed information dissemination (90.9\%) as a primary goal, with service promotion $(54.4 \%)$, improving reach (45.5\%), and interactive communication (45.5\%) also noted. Importantly, most organizations have several goals for social media adoption including providing accurate and timely information among the top

\section{Table 2. Organizational Goals Related to Social Media Use}

\begin{tabular}{|c|c|c|c|}
\hline Themes & Examples & Count & Proportion \\
\hline $\begin{array}{l}\text { Information } \\
\text { dissemination }\end{array}$ & $\begin{array}{l}\text { Our main goal is to make sure that our residents are prepared } \\
\text { and know who to follow for accurate information. }\end{array}$ & 10 & $90.90 \%$ \\
\hline Service promotion & $\begin{array}{l}\text { Our goal in using social media is to build two-way } \\
\text { communication, to solve the citizens' issues and problems, and } \\
\text { to promote our services. }\end{array}$ & 6 & $54.40 \%$ \\
\hline Improving reach & $\begin{array}{l}\text { In general, we are trying to reach a wide audience by age } \\
\text { groups, gender, etc. and get out information as quickly as } \\
\text { possible. }\end{array}$ & 5 & $45.50 \%$ \\
\hline $\begin{array}{l}\text { Interactive } \\
\text { communication }\end{array}$ & $\begin{array}{l}\text { Our strategy for using social media is "know us before you } \\
\text { need us." We want to build a positive relationship with our } \\
\text { citizens. We want citizens to interact with us in a more friendly } \\
\text { and casual manner [on social media], so that they are closer } \\
\text { to us. }\end{array}$ & 5 & $45.40 \%$ \\
\hline Timeliness & $\begin{array}{l}\text { Our primary goal is to use social media to deliver information } \\
\text { quickly into the community. }\end{array}$ & 4 & $36.40 \%$ \\
\hline Mitigating rumors & $\begin{array}{l}\text { [Our goal is to] reach our citizens and mitigate any sort of } \\
\text { rumors. }\end{array}$ & 4 & $36.40 \%$ \\
\hline $\begin{array}{l}\text { Attract other media/ } \\
\text { agencies }\end{array}$ & $\begin{array}{l}\text { We post everything about our agency on [Facebook], such as } \\
\text { news reports, important meetings, and things that we think our } \\
\text { citizens are interested in... we also make a huge investment in } \\
\text { our Facebook to attract our audiences and other media. }\end{array}$ & 2 & $18.20 \%$ \\
\hline
\end{tabular}

priorities. This is consistent with existing literature observing that agencies use social media more for informing and notification rather than interaction and relationship building (Edlins \& Bainard, 2016).

Interestingly, two counties specifically mentioned emphasizing one-way communication, noting that social media was not their preferred venue for dialogue:

We use our social media platforms for one-way information dissemination on purpose. We know the function of communication is important too, but because of potential legal concerns we don't emphasize it.

Our primary goal for using social media is to disseminate information. We don't want to emphasize two-way communication. We encourage our citizens to contact us through hotlines, because it's easier to deliver more detailed and customized information.

This indicates that organizations may need to reassess both one-way and two-way communications in light of a more comprehensive and flexible strategy. For example, content analysis demonstrates 
October 7, 2016 :

\title{
Hurricane Matthew has left many County households without power. Every effort is being made to restore power outages as soon as possible. Try to be patient; outages may last several days or more.
}

\author{
If you are a City \\ customer please call: \\ If you are a Florida Power \& Light customer please call: (800)

\section{6-3545}

\#Matthew

$00 \% 8$

\section{Comments 22 Shares}

that organizations can specifically indicate when and where that the public can ask questions or give feedback through a specific channel. An example of this is provided in Figure 3.

When asked about perceptions of public expectations, primary themes among responses include providing timely response $(81.80 \%)$ and adequate amounts of information (63.60\%) (see Table 3 ). Several respondents indicated that residents expect to hear from them on social media "immediately". Content analysis echoed poor perceptions of the county when these updates were not provided per

Table 3. Public Managers' Perceptions of Citizen Expectations of Social Media Communication

\begin{tabular}{|c|c|c|c|}
\hline Themes & Examples & Count & Proportion \\
\hline Timeliness & $\begin{array}{l}\text { Our citizens want to hear from us, and want to hear from us } \\
\text { immediately, on our social media page. }\end{array}$ & 9 & $81.80 \%$ \\
\hline Information Volume & $\begin{array}{l}\text { During the emergency, our citizens expect us to provide as much } \\
\text { information as we can on social media. }\end{array}$ & 7 & $63.60 \%$ \\
\hline Accuracy & $\begin{array}{l}\text { I think our citizens want to get } 100 \% \text { correct information from } \\
\text { our county's Facebook page. }\end{array}$ & 6 & $54.50 \%$ \\
\hline Ease of Access & $\begin{array}{l}\text { I think during the emergency, our people want to hear from us. } \\
\text { They expect that we can help them and tell them what to do. We } \\
\text { try to let people know we are with them the entire time. }\end{array}$ & 6 & $54.50 \%$ \\
\hline Engagement & $\begin{array}{l}\text { One thing we learned from our experience is that our citizens } \\
\text { want to provide input on our social media for emergency } \\
\text { management. We received a lot of information and feedback } \\
\text { from our citizens. It helps to build our community, especially } \\
\text { during a hard time. }\end{array}$ & 4 & $36.40 \%$ \\
\hline $\begin{array}{l}\text { Personalized direct } \\
\text { messages }\end{array}$ & $\begin{array}{l}\text { I feel like people started to move to not only being updated, but } \\
\text { being updated constantly, even if there is not an update to give. } \\
\text { They expect messages to be extremely personal (what would } \\
\text { affect me personally). }\end{array}$ & 3 & $27.30 \%$ \\
\hline Transparency & $\begin{array}{l}\text { Citizens expect transparency, and timely updating. They want } \\
\text { information that is relevant to them. }\end{array}$ & 1 & $9.10 \%$ \\
\hline
\end{tabular}




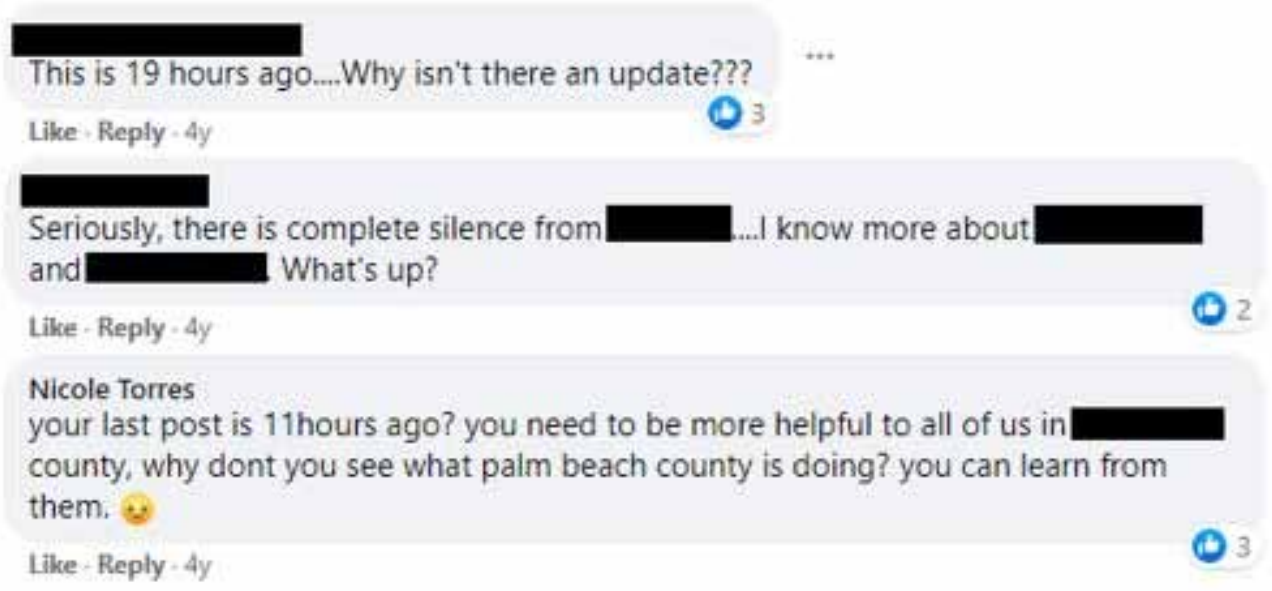

expectations, as seen in Figure 4. Other expectations include providing accurate information (54.50\%), being accessible (54.50\%), opportunities for engaging with the government (36.40\%), providing personalized direct messages $(27.30 \%)$, and being transparent $(9.10 \%)$. Related to engagement, many organizations noted the demand for direct messaging, but had contrasting opinions of its utility. While some believe it facilitates higher quality interaction, others note that they don't have sufficient staff to consistently monitor direct messages.

In order to better understand how agencies managed their social media during the emergency, we asked if specific employees were assigned to update and manage social media accounts. Every agency $(\mathrm{N} 2=11)$ responded that they have at least one specific staff-person assigned to oversee the social media account. Eight agencies $(72.7 \%, \mathrm{~N} 2=11)$ reported that the Emergency Management Director/ Manager/Planner supervised all the social media activities. The other three agencies assigned the role to employees with the job titles Marketing and Communication Manager, Public Information Officer, and Digital Marketing Manager. Five agencies (45.5\%) indicated that they had assigned multiple staff (ranging from three to five people) to manage their accounts. Two agencies (18.2\%) mentioned that they also hired an external social media specialist to monitor accounts. Based on interview data, the two agencies with the highest number of posts both highlighted having multiple staff members charged with social media, all under central leadership. The agency with the highest volume of posts also utilized volunteers to assist with content management, under the supervision of a social media specialist. With this variation in responsibilities for developing content in mind, one organization mentioned:

In EOC activation we bring in more folks, everyone takes on individual roles and the social media team gets messages out, responds to questions, and handles rumors. We have 5 people on the social media desk organized by platform with a social media lead and a team lead.

Additionally, organizations noted that they have both formal and informal policies for posting, updating, and communicating with the public. Internal policies related to post content were often informal with the exception of an activation, and social media policies were used to regulate public commentary.

Explicitly listed in ours about section on our Facebook page is our social media policy. We block profanity and note that if you are posting something unrelated to the topic you can be hidden because it takes away from the messages that we send.

Content Variations and Engagement 
The second aim of this study was to understand how variations in content relate to differences in levels of engagement among the public. This question is explored in three ways, integrating qualitative and quantitative data. First, we provide a summary of the content format used among the entire 24

Table 4. Frequency Distribution of Social Media Content

\begin{tabular}{|l|l|l|}
\hline Types of Post & N & $\%$ \\
\hline Plain text & 529 & $55.4 \%$ \\
\hline Picture & 356 & $37.3 \%$ \\
\hline Video & 70 & $7.3 \%$ \\
\hline Total $(\%)$ & 955 & $100 \%$ \\
\hline
\end{tabular}

county sample across the entire timeline (see Table 4). Of the 955 total posts from all agencies, 529 (55.4\%) were in plain text format, 365 (27.3\%) were pictures, and $70(7.2 \%)$ were videos.

We then analyzed differences in interactivity based on content format, using a one-way ANOVA test. Many prior studies have used the number of likes, comments, and shares under Facebook posts as indicators of public engagement with organizations (Cho et al., 2014; Agostino \& Arnaboldi, 2016). We use this working assumption with an index combining the total number of likes, comments, and shares to reflect citizen interaction with posts. Due to the residuals of interaction having a skewed distribution, a natural log transformation was used before running the ANOVA test. Table 5 shows

Table 5. One-Way ANOVA of Citizens' Interaction on Different Types of Social Media Content

\begin{tabular}{|l|l|l|l|l|l|}
\hline & $\begin{array}{l}\text { Sum of } \\
\text { Squares }\end{array}$ & df & Mean Square & F & p-value \\
\hline Between Groups & 18.19 & 2 & 9.09 & 3.13 & $* * 0.04$ \\
\hline Within Groups & 2577.43 & 886 & 2.90 & & \\
\hline Total & 2595.62 & 888 & & & \\
\hline
\end{tabular}

*Dependent variable: $\operatorname{Ln}($ Interaction)

the one-way ANOVA results. The results demonstrate a statistically significant difference among citizens' levels of interaction with the varying content formats $(\mathrm{F}=3.13, \mathrm{p}=0.04)$.

A Tukey post hoc test was used to explore these differences (see Table 6). The results indicate a weak statistically significant difference between citizens' reactions to Facebook posts containing photos, and posts containing videos, with citizens most likely to interact with video posts (mean difference $=-0.48, \mathrm{p}<.01$ ). No statistically significant difference was found between plain text and photos, or plain text and video. This indicates that in this case, narrative content was still interactive.

Interview results paint a more comprehensive picture. Generally, most agencies (63.6\%) were aware of using different forms of social media content as has been suggested by the literature (Pittman \& Reich, 2016). However, some staff remarked that relying on visual content is not always a good idea, because citizens can misinterpret visual content and need the government to provide more clear explanations and guidance. In addition, some agencies noted citizen feedback that picture and video content were inconvenient. One respondent raised the following observation: 
Table 6. Post Hoc Tests of Citizens' Interaction on Different Types of Social Media Content

\begin{tabular}{|c|c|c|c|c|c|c|}
\hline \multirow[b]{2}{*}{ (I) Types } & \multirow[b]{2}{*}{ (J) Types } & \multirow{2}{*}{$\begin{array}{l}\text { Mean Difference } \\
\text { (I-J) }\end{array}$} & \multirow[b]{2}{*}{ Std. Error } & \multirow[b]{2}{*}{ Sig. } & \multicolumn{2}{|c|}{ 95\% Confidence Interval } \\
\hline & & & & & Lower Bound & Upper Bound \\
\hline \multirow[t]{2}{*}{ Text } & Picture & 0.23 & 0.12 & 0.13 & -0.05 & 0.52 \\
\hline & Video & -0.25 & 0.23 & 0.51 & -0.78 & 0.28 \\
\hline \multirow[t]{2}{*}{ Picture } & Text & -0.23 & 0.12 & 0.13 & -0.52 & 0.05 \\
\hline & Video & -0.48 & 0.23 & $0.09 *$ & -1.03 & 0.06 \\
\hline \multirow[t]{2}{*}{ Video } & Text & 0.25 & 0.23 & 0.51 & -0.28 & 0.78 \\
\hline & Picture & 0.48 & 0.23 & $0.09 *$ & -0.06 & 1.03 \\
\hline
\end{tabular}

We recently heard feedback from a citizen that viewing pictures or videos on social media takes up a lot of battery [on their smartphones]. Sometimes, it's hard for citizens to watch visual content on their phones when the power is out.

Because staff are trained to carefully assess and organize information before disseminating to the public, they are prudent in using creative visual information during emergencies (Hughes \& Palen, 2012; Wukich, 2020). During interviews, six agencies (54.5\%) mentioned that they were also concerned about post length, in addition to content format.

\section{Practitioner Reflections}

The final component of our study asked interviewees to describe practical lessons from their experience. These observations illustrate some of the friction between scholarly recommendations and practitioner implementation, which also draws new questions for future research based on qualitative inquiry.

First, many respondents $(90 \%, \mathrm{~N} 2=11)$ indicated that the ability to deliver real-time information to their citizens before, during, and after the hurricane was generally quite successful from their perspective. $45 \%$ of agencies $(\mathrm{N} 2=11)$ indicated that social media helped them to build citizen trust. Approximately $55 \%$ of agencies $(\mathrm{N} 2=11)$ also expressed that social media gave them the opportunity to reach more citizens directly than they would have been able to accomplish through other channels. Traditional media is still a useful tool for emergency management agencies in sending out information. However, three agencies (27.3\%) observed that the relationships among the agencies, the media, and the public have changed since the adoption of social media. One respondent indicated:

We don't depend on a third party anymore to help deliver news. Instead, a lot of these traditional media outlets contact us if they see something interesting from our social media accounts. Social media is not a supplementary tool anymore. It's a primary tool.

In the interviews, many also shared some important issues in reach, technology, capacity, and boundary problems. Although the majority appreciated the incredible reach capabilities of social media, $63.60 \%$ of the respondents $(\mathrm{N} 2=11)$ mentioned they still had challenges related to accessing a broad array of citizens. Existing research shows that certain populations, such as seniors, those with limited English proficiency, and people with disabilities, are hard to connect with through social media (Bertot et al., 2012). In our sample, one respondent mentioned that they have adopted multiple languages, including sign language, on their social media platform to try to address some of these challenges. Furthermore, Facebook offers an auto-translation feature, which may be useful, although additional research is needed to understand if this feature is helpful or not for information accuracy. Additionally, agencies could also actively target "information brokers" (e.g., those who are tech savvy), who can help to deliver information from social media to special populations. For 
instance, other studies have indicated that younger generations can effectively facilitate their families' connection to public information, especially in immigrant communities (Katz, 2014).

Reflecting the networked approach to emergency management, organizations mentioned broad challenges associated with ensuring consistency in information and working with both partners in other sectors, as well as corresponding agencies at other levels in information dissemination. While scholars suggest using a central command center communication infrastructure involving multiple stakeholders (Wukich, 2020), respondents note:

Certain agencies didn't want to rely on our Emergency Operations Center. For example, the PIO from our Sheriff's office wanted to post her own information on her social media page.

Additionally, respondents cited challenges with respect to rumor control and monitoring. Due to the rapid nature of information dissemination, there are challenges with vetting information before agencies pass it along to the public. Emergency management agencies must take on more responsibility to frequently assess information in various outlets (Wukich, 2020). One respondent provided a potential solution, noting that organizations could store published posts from prior emergencies, evaluate and summarize the data. This pre-writing strategy could shorten preparation time and allow the organizations to adjust and update accordingly if, and when, situations change. Building a content database could also help organizations to track their experiences and give extra attention to previous mistakes and communication weaknesses.

We summarize practitioner challenges and scholarly recommendations, as well as practical recommendations in Table 7.

Table 7. Public Managers' Perceptions of Challenges and Successes

\begin{tabular}{|c|c|c|}
\hline Suggestions from Existing Literature & Implementation Challenges & $\begin{array}{l}\text { Recommendations for Practitioners } \\
\text { \& Future Research }\end{array}$ \\
\hline $\begin{array}{l}\text { Interaction and Engagement } \\
\text { Increased use of two-way communication } \\
\text { (Mergel, 2013; Houston et al., 2015; Wukich \& } \\
\text { Mergel, 2016; Plotnick \& Hiltz, 2016; Chatfield \& } \\
\text { Reddick, 2019) }\end{array}$ & $\begin{array}{l}1 \text { Two-way communication is not always } \\
\text { useful during event } \\
1 \text { Additional staff needed to monitor two- } \\
\text { way communication channels } \\
1 \text { Expectation of fast response time from } \\
\text { public can be difficult to meet }\end{array}$ & $\begin{array}{l}1 \text { Adopt one-way communication primarily } \\
\text { when agency needs to disseminate information } \\
\text { to the public during the event; Adopt two-way } \\
\text { primarily before and after the event } \\
1 \text { Consider redirecting to other channels (e.g. } \\
\text { direct messages, hotlines) for interactive } \\
\text { communication }\end{array}$ \\
\hline $\begin{array}{l}\text { Timely, High Quality and Innovative Content } \\
\text { Inform the public of information that is certain, } \\
\text { who is affected, what they should do, who they } \\
\text { can trust (Ulmer et al., 2017); ensure speedy } \\
\text { communication (Graham et al., 2015); provide } \\
\text { customized and innovative content (Gruzd et al. } \\
\text { 2018) }\end{array}$ & $\begin{array}{l}\text { 1 Situation constantly changes, prompting } \\
\text { need for many updates for busy staff } \\
1 \text { Rich content loading drains batteries on } \\
\text { mobile devices } \\
1 \text { Unknown variations in engagement with } \\
\text { different forms of content }\end{array}$ & $\begin{array}{l}\text { 1 Allocate a budget for social media use; hire } \\
\text { temporary staff or volunteers for emergency } \\
\text { events } \\
1 \text { Document effective social media content and } \\
\text { responses from the past events for future use } \\
\text { l Ensure content follows accessibility guidelines. } \\
\text { Use short video clips instead of long recorded } \\
\text { conferences } \\
\text { l Ensure transparency about agency } \\
\text { communication limitations; provide follow up } \\
\text { information for questions }\end{array}$ \\
\hline $\begin{array}{l}\text { Content Policy and Task Management } \\
\text { Adopt a social media policy (Bennet \& } \\
\text { Manoharan, 2017); changing role of PIO includes } \\
\text { monitoring and controlling messaging that public } \\
\text { can contribute to, making assignment of tasks } \\
\text { relevant (Hughes \& Palen, 2012; Wukich, 2020) }\end{array}$ & $\begin{array}{l}\text { 1 Social media content updates filtered } \\
\text { through one high staff member with } \\
\text { additional duties } \\
1 \text { Monitoring rumors and information } \\
\text { inaccuracy }\end{array}$ & $\begin{array}{l}\text { 1 Social media policy can contribute to quality } \\
\text { public generated content by being posted } \\
\text { publicly; irrelevant or inappropriate content can } \\
\text { be hidden } \\
1 \text { Designate a specific social media specialist } \\
\text { (internal or external) with authority over content }\end{array}$ \\
\hline $\begin{array}{l}\text { Improving Population Reach } \\
\text { Reach broad audiences in rural and underserved } \\
\text { areas, as well as those with limited language } \\
\text { or technology proficiency (Graham et al, 2015; } \\
\text { Mergel, 2013; Neely \& Collins, 2018) }\end{array}$ & $\begin{array}{l}1 \text { Challenge in reaching diverse, broad, } \\
\text { and underserved audiences through social } \\
\text { media }\end{array}$ & $\begin{array}{l}1 \text { Attract more "information brokers," such as } \\
\text { youth, local churches, or community centers to } \\
\text { reach out to broad audiences indirectly } \\
1 \text { Provide information in multiple languages } \\
1 \text { Build community engagement outside of social } \\
\text { media prior to event }\end{array}$ \\
\hline
\end{tabular}




\section{CONCLUSION}

The use of social media platforms by governments is now one of the most important sources for delivering emergency management content. The first contribution in this study is to understand and confirm that the nature and management of social media during emergencies is evolving. First, while social media are often used in unidirectional pushes of information, just under half of this study's sample indicated interactive communication as a top priority in their social media strategy. While building two-way communication is important, the study further explored the nuances in personnel management and content creation, confronted when actually using this strategy in an emergency scenario. With this in mind, agencies could explore integrating flexible strategies-emphasizing one-way communication during phases where the public expects larger volumes of information (for instance, in preparedness), and two-way communication where the public might have individualized needs (for instance, during response).

The second focus of this study is to identify significant differences in interaction among various content formats. Given the 2016 release of the video feature on Facebook, we are confident that more agencies have adopted this tactic in recent years. Considering the urgent timeframe and limited resources, agencies should think strategically about their use of visual content, potentially providing updates with high frequency but in short content-form content. We also suggest that when communicating with the public on social media, content creators should show strong emotional support, especially during the response and recovery stages. Clear, accurate, and compassionate information can help comfort the public after a disaster. Following the completion of this study, Facebook launched emoji reactions, which could be used by future studies to assess public interaction.

Our research is not without limitations. This study only selected a few emergency management agencies at the county level in one southern state, limiting generalizability. Future studies could expand the analysis scale by considering other stakeholders from other sectors or levels of governments. Also, Hurricane Matthew was the first major hurricane to hit Florida since 2005, and many agencies had only used limited functions on social media to deal with local emergency hazards by that point. Many organizations were also inactive on social media during Hurricane Matthew, which restricted the secondary data collected from Facebook posts. Future research could explore a similar topic in the context of different hazards. In addition, our study focused on the perspectives of public managers. Future studies should expand the study's scale by evaluating the online engagement from citizens' perspective. 


\section{REFERENCES}

Agostino, D., \& Arnaboldi, M. (2016). A measurement framework for assessing the contribution of social media to public engagement: An empirical analysis on Facebook. Public Management Review, 18(9), 1289-1307. do i:10.1080/14719037.2015.1100320 doi:10.1080/14719037.2015.1100320

Aldrich, D. P., \& Meyer, M. A. (2015). Social capital and community resilience. The American Behavioral Scientist, 59(2), 254-269. doi:10.1177/0002764214550299 doi:10.1177/0002764214550299

Bertot, J. C., Jaeger, P. T., \& Hansen, D. (2012). The impact of polices on government social media usage: Issues, challenges, and recommendations. Government Information Quarterly, 29(1), 30-40. doi:10.1016/j. giq.2011.04.004 doi:10.1016/j.giq.2011.04.004

Briones, R. L., Kuch, B., Liu, B. F., \& Jin, Y. (2011). Keeping up with the digital age: How the American Red Cross uses social media to build relationships. Public Relations Review, 37(1), 37-43. doi:10.1016/j. pubrev.2010.12.006 doi:10.1016/j.pubrev.2010.12.006

Chatfield, A. T., \& Reddick, C. G. (2018). All hands on deck to tweet\# sandy: Networked governance of citizen coproduction in turbulent times. Government Information Quarterly, 35(2), 259-272. doi:10.1016/j. giq.2017.09.004 doi:10.1016/j.giq.2017.09.004

Cho, M., Schweickart, T., \& Haase, A. (2014). Public engagement with nonprofit organizations on Facebook. Public Relations Review, 40(3), 565-567. doi:10.1016/j.pubrev.2014.01.008 doi:10.1016/j.pubrev.2014.01.008

Creswell, J. W., \& Clark, V. L. P. (2017). Designing and conducting mixed methods research. Sage Publications.

Facebook. (2018). https://newsroom.fb.com/company-info/

FEMA (Federal Emergency Management Agency). (2019). FEMA Comprehensive Preparedness Guide 101. FEMA.

FEMA's Emergency Management Institute. (2010). https://www.fema.gov/media-librarydata/20130726-1828-25045-0014/cpg_101_comprehensive_preparedness_guide_developing_and_maintaining_ emergency_operations_plans_2010.pdf

Garnett, J. L., \& Kouzmin, A. (2007). Communicating throughout Katrina: Competing and complementary conceptual lenses on crisis communication. Public Administration Review, 67, 171-188. doi:10.1111/j.15406210.2007.00826.x doi:10.1111/j.1540-6210.2007.00826.x

Gelo, O., Braakmann, D., \& Benetka, G. (2008). Quantitative and qualitative research: Beyond the debate. Integrative Psychological \& Behavioral Science, 42(3), 266-290. doi:10.1007/s12124-008-9078-3 PubMed doi:10.1007/s12124-008-9078-3 PMID:18795385

Graham, M. W., Avery, E. J., \& Park, S. (2015). The role of social media in local government crisis communications. Public Relations Review, 41(3), 386-394. doi:10.1016/j.pubrev.2015.02.001 doi:10.1016/j.pubrev.2015.02.001

Gruzd, A., Lannigan, J., \& Quigley, K. (2018). Examining government cross-platform engagement in social media: Instagram vs Twitter and the big lift project. Government Information Quarterly, 35(4), 579-587. doi:10.1016/j. giq.2018.09.005 doi:10.1016/j.giq.2018.09.005

Hiltz, S. R., Kushma, J. A., \& Plotnick, L. (2014). Use of social media by US public sector emergency managers: Barriers and wish lists. ISCRAM. 10.13140/2.1.3122.4005

Houston, J. B., Hawthorne, J., Perreault, M. F., Park, E. H., Goldstein Hode, M., Halliwell, M. R., Turner McGowen, S. E., Davis, R., Vaid, S., McElderry, J. A., \& Griffith, S. A. (2015). Social media and disasters: A functional framework for social media use in disaster planning, response, and research. Disasters, 39(1), 1-22. doi:10.1111/disa.12092 PubMed doi:10.1111/disa.12092 PMID:25243593

Hughes, A. L., \& Palen, L. (2012). The evolving role of the public information officer: An examination of social media in emergency management. Journal of Homeland Security and Emergency Management, 9(1). Advance online publication. doi:10.1515/1547-7355.1976 doi:10.1515/1547-7355.1976

Kagarise, W., \& Zavattaro, S. M. (2017). Social media: How one city opens the evidence black box. Public Administration Review, 77(4), 486-488. doi:10.1111/puar.12696 doi:10.1111/puar.12696 
Kaplan, A. M., \& Haenlein, M. (2010). Users of the world, unite! The challenges and opportunities of Social Media. Business Horizons, 53(1), 59-68. doi:10.1016/j.bushor.2009.09.003 doi:10.1016/j.bushor.2009.09.003

Kapucu, N. (2008). Collaborative emergency management: Better community organising, better public preparedness and response. Disasters, 32(2), 239-262. doi:10.1111/j.1467-7717.2008.01037.x PubMed doi:10.1111/j.1467-7717.2008.01037.x PMID:18380853

Katz, V. (2014). Children as brokers of their immigrant families' health-care connections. Social Problems, 61(2), 194-215. doi:10.1525/sp.2014.12026 doi:10.1525/sp.2014.12026

Kavanaugh, A. L., Fox, E. A., Sheetz, S. D., Yang, S., Li, L. T., Shoemaker, D. J., Natsev, A., \& Xie, L. (2012). Social media use by government: From the routine to the critical. Government Information Quarterly, 29(4), 480-491. doi:10.1016/j.giq.2012.06.002 doi:10.1016/j.giq.2012.06.002

Latonero, M., \& Shklovski, I. (2013). Emergency management, Twitter, and social media evangelism. In Using social and information technologies for disaster and crisis management (pp. 196-212). IGI Global. doi:10.4018/978-1-4666-2788-8.ch013 doi:10.4018/978-1-4666-2788-8.ch013

Liu, B. F., Horsley, J. S., \& Yang, K. (2012). Overcoming negative media coverage: Does government communication matter? Journal of Public Administration: Research and Theory, 22(3), 597-621. doi:10.1093/ jopart/mur078 doi:10.1093/jopart/mur078

Luna, S., \& Pennock, M. J. (2018). Social media applications and emergency management: A literature review and research agenda. International Journal of Disaster Risk Reduction, 28, 565-577. doi:10.1016/j.ijdrr.2018.01.006 doi:10.1016/j.ijdrr.2018.01.006

Martinez-Rojas, M., Pardo-Ferreira, M., \& Rubio-Romero, J. C. (2018). Twitter as a tool for the management and analysis of emergency situations: A systematic literature review. International Journal of Information Management, 43, 196-208. doi:10.1016/j.ijinfomgt.2018.07.008 doi:10.1016/j.ijinfomgt.2018.07.008

Medina, P. S., \& Bryer, T. A. (2019). Limitations of Assessing Citizen Engagement Through Local Government Social Media Rankings: Implications for Policy and Practice. International Journal of Policy Studies, 10(1), 57-77.

Meltzer, M., Ștefănescu, L., \& Ozunu, A. (2018). Keep Them Engaged: Romanian County Inspectorates for Emergency Situations' Facebook Usage for Disaster Risk Communication and Beyond. Sustainability, 10(5), 1411. doi:10.3390/su10051411 doi:10.3390/su10051411

Mergel, I. (2013). A framework for interpreting social media interactions in the public sector. Government Information Quarterly, 30(4), 327-334. doi:10.1016/j.giq.2013.05.015 doi:10.1016/j.giq.2013.05.015

Neely, S. R., \& Collins, M. (2018). Social media and crisis communications: A survey of local governments in Florida. Journal of Homeland Security and Emergency Management, 15(1), 20160067. Advance online publication. doi:10.1515/jhsem-2016-0067 doi:10.1515/jhsem-2016-0067

Norris, D. F., \& Reddick, C. G. (2013). Local e-government in the United States: Transformation or incremental change? Public Administration Review, 73(1), 165-175. doi:10.1111/j.1540-6210.2012.02647.x doi:10.1111/ j.1540-6210.2012.02647.x

Pittman, M., \& Reich, B. (2016). Social media and loneliness: Why an Instagram picture may be worth more than a thousand Twitter words. Computers in Human Behavior, 62, 155-167. doi:10.1016/j.chb.2016.03.084 doi:10.1016/j.chb.2016.03.084

Plotnick, L., \& Hiltz, S. R. (2016). Barriers to use of social media by emergency managers. Journal of Homeland Security and Emergency Management, 13(2), 247-277. doi:10.1515/jhsem-2015-0068 doi:10.1515/ jhsem-2015-0068

Reuters. (2016, Oct. 7). 4 States Declare Emergency as Hurricane Matthew Closes in on Florida. Fortune. https:// fortune.com/2016/10/07/hurricane-matthew-florida-emergency-evacuate/

Statista. (2020). Number of monthly active Facebook users worldwide as of 4th quarter 2019. https://www. statista.com/statistics/264810/number-of-monthly-active-facebook-users-worldwide/

Toomela, A. (2008). Variables in psychology: A critique of quantitative psychology. Integrative Psychological \& Behavioral Science, 42(3), 245-265. doi:10.1007/s12124-008-9059-6 PubMed doi:10.1007/s12124-0089059-6 PMID:18528738 
Ulmer, R. R., Sellnow, T. L., \& Seeger, M. W. (2017). Effective crisis communication: Moving from crisis to opportunity. Sage Publications.

Wang, J., Wu, Y., Yen, N., Guo, S., \& Cheng, Z. (2016). Big data analytics for emergency communication networks: A survey. IEEE Communications Surveys and Tutorials, 18(3), 1758-1778. doi:10.1109/COMST.2016.2540004 doi:10.1109/COMST.2016.2540004

Wukich, C. (2020). More Monitoring, Less Coordination: Twitter and Facebook Use between Emergency Management Agencies. Journal of Homeland Security and Emergency Management, 17(3), 20200007. doi:10.1515/jhsem-2020-0007 doi:10.1515/jhsem-2020-0007

Wukich, C., \& Mergel, I. (2016). Reusing social media information in government. Government Information Quarterly, 33(2), 305-312. doi:10.1016/j.giq.2016.01.011 doi:10.1016/j.giq.2016.01.011

Xu, Z., Liu, Y., Yen, N., Mei, L., Luo, X., Wei, X., \& Hu, C. (2016). Crowdsourcing based description of urban emergency events using social media big data. IEEE Transactions on Cloud Computing, 8(2), 387-397. doi:10.1109/TCC.2016.2517638 doi:10.1109/TCC.2016.2517638

Yates, D., \& Paquette, S. (2011). Emergency knowledge management and social media technologies: A case study of the 2010 Haitian earthquake. International Journal of Information Management, 31(1), 6-13. doi:10.1016/j. ijinfomgt.2010.10.001 doi:10.1016/j.jinfomgt.2010.10.001

Yuan, F., Li, M., \& Liu, R. (2020). Understanding the evolutions of public responses using social media: Hurricane Matthew case study. International Journal of Disaster Risk Reduction, 51, 101798. doi:10.1016/j. ijdrr.2020.101798 doi:10.1016/j.ijdrr.2020.101798 


\section{APPENDIX 1}

\section{List of Interview Respondents}

\begin{tabular}{|c|c|c|c|c|c|}
\hline County & Population & $\begin{array}{l}\text { \% non- } \\
\text { White }\end{array}$ & $\begin{array}{l}\text { Median } \\
\text { Household } \\
\text { Income }\end{array}$ & $\begin{array}{l}\text { Computer } \\
\text { and } \\
\text { Internet } \\
\text { Use }\end{array}$ & Mission as described on Facebook \\
\hline Alachua & 266,944 & 30 & $\$ 44,702$ & $89 \%$ & $\begin{array}{l}\text { Supporting our whole community before, during, } \\
\text { and after a disaster }\end{array}$ \\
\hline Bradford & 27,038 & 22.4 & $\$ 43,373$ & $72.8 \%$ & $\begin{array}{l}\text { Bradford County Emergency Management is a } \\
\text { Division of the Bradford County Sheriff's Office } \\
\text { and is tasked with the preparation, planning, } \\
\text { response, and recovery for any emergency or } \\
\text { event that may threaten our population. }\end{array}$ \\
\hline $\begin{array}{l}\text { Brevard County } \\
\text { Emergency } \\
\text { Management }\end{array}$ & 589,162 & 16.6 & $\$ 49,914$ & $89.9 \%$ & $\begin{array}{l}\text { This Facebook account is where you will find the } \\
\text { most recent news, stories, videos and photos that } \\
\text { are distributed by the County. }\end{array}$ \\
\hline $\begin{array}{l}\text { Clay County } \\
\text { Emergency } \\
\text { Management }\end{array}$ & 212,230 & 18.9 & $\$ 59,175$ & $93.1 \%$ & $\begin{array}{l}\text { Clay County Emergency Management's mission } \\
\text { is to keep the citizens and visitors of Clay County } \\
\text { safe and informed. }\end{array}$ \\
\hline $\begin{array}{l}\text { Indian River } \\
\text { County Emergency } \\
\text { Management }\end{array}$ & 154,383 & 13 & $\$ 47,446$ & $85.6 \%$ & $\begin{array}{l}\text { The purpose of the Indian River County } \\
\text { Emergency Management social media platform } \\
\text { is to provide information of public interest to the } \\
\text { county's residents, business community, visitors } \\
\text { and other members of the general public. }\end{array}$ \\
\hline $\begin{array}{l}\text { Levy County } \\
\text { Emergency } \\
\text { Management }\end{array}$ & 40,355 & 12.9 & $\$ 35,480$ & $79.7 \%$ & $\begin{array}{l}\text { To keep the citizens and visitors of Levy County } \\
\text { safe and informed. }\end{array}$ \\
\hline $\begin{array}{l}\text { Orange County } \\
\text { Emergency } \\
\text { Management }\end{array}$ & $1,348,975$ & 31.9 & $\$ 49,391$ & $91.8 \%$ & $\begin{array}{l}\text { Our mission is to serve the citizens of Orange } \\
\text { County and our guests with integrity, honesty, } \\
\text { fairness and professionalism. We are committed } \\
\text { to engaging our citizens in the decision making } \\
\text { process in order to earn their trust and improve } \\
\text { our quality of life. }\end{array}$ \\
\hline $\begin{array}{l}\text { Palm Beach } \\
\text { County Emergency } \\
\text { Management }\end{array}$ & $1,471,150$ & 25 & $\$ 55,277$ & $89.2 \%$ & $\begin{array}{l}\text { To minimize the impact of emergencies and } \\
\text { disasters to our community through education, } \\
\text { planning, and response by coordinating } \\
\text { information and resources. }\end{array}$ \\
\hline $\begin{array}{l}\text { Seminole County } \\
\text { Emergency } \\
\text { Management }\end{array}$ & 462,659 & 20.6 & $\$ 58,538$ & $94 \%$ & $\begin{array}{l}\text { Seminole County Emergency Management } \\
\text { responds to emergencies that threaten life and } \\
\text { property daily. A proactive approach is taken in } \\
\text { many of these emergency situations by extensive } \\
\text { training and disaster planning. The department } \\
\text { operates under the Incident Management System } \\
\text { of incident Command for both daily operations } \\
\text { and alarm situations. }\end{array}$ \\
\hline $\begin{array}{l}\text { St. Johns County } \\
\text { Emergency } \\
\text { Management }\end{array}$ & 243,812 & 11 & $\$ 69,532$ & $92.5 \%$ & $\begin{array}{l}\text { Our mission is to ensure emergency preparedness } \\
\text { by developing and implementing comprehensive } \\
\text { disaster planning, mitigation and response } \\
\text { capabilities to protect the lives and property of the } \\
\text { citizens of St. Johns County. }\end{array}$ \\
\hline $\begin{array}{l}\text { St. Lucie County } \\
\text { Emergency } \\
\text { Management }\end{array}$ & 313,506 & 25.6 & $\$ 44,140$ & $87.3 \%$ & $\begin{array}{l}\text { To provide service, infrastructure and leadership } \\
\text { necessary to advance a safe and sustainable } \\
\text { community, maintain a high quality of life, } \\
\text { and protect the natural environment for all our } \\
\text { citizens. }\end{array}$ \\
\hline
\end{tabular}


Wanzhu Shi is Assistant Professor in the Master of Public Administration program at Texas A\&M International University. Her current research interests focus on social media usage in public sectors, and community assessment. Her most recent work has been published in the International Journal of Public Administration in the Digital Age.

Pamela Media is Assistant Professor of Public Administration at California State University San Bernardino. Her research interests include citizen-administrator relations, civil society, and technology facilitated civic engagement. Her most recent work has been published in the journal of Health and Human Services Administration, and the International Journal of Policy Studies. 